\title{
Széklettranszplantáció hatékonysága és feltételezhető hatásmechanizmusai
}

- Péterfi Zoltán dr., Vincze Áron dr.

Pécsi Tudomanyegyetem, l. sz Belgyógyászati Klinika, Pécs

Correspondence: peterfi.zoltan@pte.hu

A széklet gyógyításra való felhasználása nem új keletű dolog. Már a negyedik században a kínaiak alkalmazták a "sárga levest" elhúzódó hasmenéses kórképek kezelésére. Állatgyógyászatban csaknem rutinszerúen alkalmazott beavatkozás. A humán gyógyászatban az elmúlt 10 évben a világjárvány kialakulásáért és a magas egészségügyi kiadásokért felelös refrakter Clostridioides difficile-fertőzések alternatív, hatékony kezelési lehetőségeként vált ismertté. Azóta számos krónikus betegség kezelésére alkalmazták és bizonyította hatékonyságát. A széklet komplex összetétele miatt az egyes betegségekben jelen ismereteinket a transzplantáció alkalmazási módjairól, indikációkról, illetve a transzplantációt követő mikrobiális és anyagcsere-változásokról.

KULCSSZAVAK: Clostridioides difficile, colitis ulcerosa, Crohn-betegség, székletmikrobióta-transzplantáció

\section{Efficacy of fecal transplantation and presumed mechanisms of}

\section{action}

Therapeutic application of faces is not a new issue, since the Chinese applied the "yellow soup" already in the 4th century to treat prolonged diarrhea. It is also a routinely used method in the veterinary practice. It is acknowledged as an alternative and effective treatment option in human health care in the last 10 years for refractory Clostridiodes difficile infection, which caused pandemic and high health care cost. This method showed efficacy in many other conditions since that time. The effective agents are not exactly known due showed efficacy in many other conditions since that time. The effective agents are not exactly known due
to the complex composition of stool. The current knowledge is shortly reviewed here about the mode of to the complex composition of stool. The current knowledge is shortly reviewed here about the mode
application, indications and the microbial and metabolic changes after fecal microbiota transplantation. KEYWORDS: Clostridioides difficile, ulcerative colitis, Crohn's disease, fecal microbiota transplantation

\section{Bevezetés}

Széklet mikrobióta-transzplantáció (fecal microbiota transplantation-FMT) alatt az egészséges donortól származó preparált széklet bejuttatását értjük a recipiens tápcsatornájába. Az FMT jelenleg rekurrens vagy refrakter Clostridioides difficile-fertőzések kezelésére elfogadott eljárás, de gyulladásos és irritábilis bélbetegségek (IBD, IBS), illetve egyéb, bélrendszeren kívüli betegségekben is vizsgálják hatékonyságát. Használatával kapcsolatosan számos aggály merül fel, mint például az eljárás kellemetlen volta az invazív adagolás szükségessége, a fertőzés átvitelének kicsi, de elismert kockázata, valamint a megfelelő donor kivallasztásảnak nehézsége (1). Az FDA felhivja a figyelmet a lehetséges súlyos kockazatokra, mint a mul reziszten kórokozók lehetséges átvitelére (2). Ez a kockázat csökkenthető a donorok megfelelő szürésével, illetve baktériummentes szürlettel végzett transzplantációval, amelyet Péterfi és munkacsoportja megfelelően hatékonynak találtak, azonban ezekkel a módszerekkel nem lehet kiszürn és megakadályozni a vírusok átvitelét. Az FMT során így akár olyan jelenleg ismeretlen mikrobák is átvihetôk, amik később esetleg krónikus betegségek kialakulásáért tehetők felelőssé.

Aktualitását az új koronavírus, SARS-CoV-2 megjelenése és pandémia kialakulása adta Több tanulmány is igazolta hogy a virus nemcsak a légúti valadékokkal, de a széklette is ürül. A székletből a fertőződés 5. napjától, a gyógyulás követően még 33-45 napon keresztül is kimutatható a vírus RNS-e, ugyanakkor ennek pontos klinikai relevanciája még nem ismert, mivel a vírus RNS kimutatása nem jelen automatikusan fertőzőképességet. Ezért az FMT alkalmazását minden esetben a kockázat-haszon mérlegeléséve kell elbírálni (3).

Az FMT rekurráló Clostridioides difficile-fertőzésben mutatott jelentős hatékonyságát nagy elemszámú, randomi zált kontrollált tanulmányok, szisztematikus összefoglaló kozlemenyek és metaanalízisek igazolták, annak ellenére, hogy a hatékonyságát alátámasztó mechanizmusok nem

D vagy IBS esetében még hiányoznak a hatékonyságo megfelelően alátámaszzó nagy esetszámú randomizált, kontrollált vizsgálatok. Kis esetszámon végzett vizsgálatok bizonyos esetekben hatekonynak bizonyultak. A C

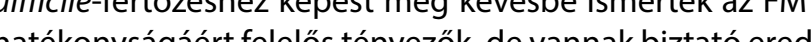

Anyagcsere-betegségek, immunológiai és neurológia rendelkezésünkre.

\section{Az FMT indikációja}

Rekurráló vagy refrakter C. difficile-infekció Megfelelően alátámasztott bizonyitékok állnak rendelMeźeleóen alatámasztott bizonyitékok állnak rendelfektológia és gasztroenterológiai társaságok $C$ difficie kezelési irányelvei magas evidenciávas javasolják alkamazását A rekurráló C difficile fertőzés eséén FMT akalmazását megelőzően ajánlott vancomycin- és/vagy fidaxomicin-kezelés megfontolása amivel a transzplantáció sikerét növelni lehet. A súlyos vagy szövődményes C. difficile-infekció (CDI) esetében az FMT elött javasolt clyan gyógyszeres kezelések megfontolása, amasol hatékonyan csökkentik a rekurrencia valószínúségét (pl. fidaxomicin). C. difficile-fertőzésben szenvedő betegek bevonásával végzett randomizált kontrollált tanulmán során szignifikánsan magasabb volt a válaszadási arány a széklettranszplantációban, mint a vancomycinkezelésben részesüló betegek között ( 94 és $90 \%$ vs. 31 és 26\%) Nagy metanalízisek többszörösen megerösítették hogy az FMT a C difficile-fertőzés hatásos gyógymódja. A gyógyulási arány $90 \%$ fölött van $(4,5)$.

Az FMT indikációját tekintve a magyar $C$. difficile diagnosztikus és terápiás módszertani levél egyértelműen fogalmaz. Többszörös rekurráló, vagy refrakter esetekben (2-3. recidíva) javasolt az antibiotikumterápia alternatívájakén alkalmazni az FMT-t, ami összhangban áll az európai infektológiai és klinikai mikrobiológiai társaság és az amerikai infektológiai társaság ajánlásával. Mindkét társaság erős ajánlással javasolja az FMT elvégzését amennyiben a megelöző antibiotikumterápia sikertelen volt $(4,6,7)$. Az európai széklettranszplantációs konszenzusajánlás elsố kezelésként nem javasolja (alacsony evidencia és kevés adat) (8). Súlyos lezajlású esetekben az antibiotikumterá- pia kiegészitése FMT-vel korábban, már 2-3. recidíva elött megfontolandó. Fulmináns lezajlás esetén, mint utolsó lehetôség johet szóba az FMT. A súlyos CDI klinikai kritériumai (2 vagy tobb jelenléte): láz $\left(>38,5^{\circ} \mathrm{C}\right)$, hidegrázás, hemodinamikai instabilitás, a szeptikus sokk jelei, peritonitis tünetei, csokkent beelhangok, hasi fajdalom es has nyomásérzékenység, ileus jelei, hányás, bélmozgások hianya, jelentós leukocytosis (fehérvérsejtszám $>15 \times 10^{9} /$ ), esetenkent leukemoid reakció, balra tolt vérkép (az összfehèrversejtszám $>20 \%$-a éretlen neutrofil), szerrumkreati(nin-szint emelkedese ( $>50 \%$ a kindulási èrtekhez képest) hzpoproteinaemia, anémia, emelkedett szérumlaktátszint, kolonoszkópiával igazolt pseudomembranosus coitis, rôntgenvizsgálattal igazolt vastagbeltágulat $(>6 \mathrm{~cm})$ kélfä eljárassal kimutatott belfal-megvastagodás, a élfal korull zsírszovet megvastagodása vagy más okka nem magyarázhato ascites.

az analis beviteli mód (

Az FMT további lehetséges, de még nem elfogadott indikációi

Colitis ulcerosa (CU)

A viromnak és a mykobiomnak is van szerepe az IBD kialakulásában. A bélmikrobiom három alkotórészének bonyolult összjátékából következően IBD esetén mindháromban változások figyelhetők meg. A betegeknél észlelt mikrobiom-változások és a gyulladásos bélbeegség súlyossága közötti igazolt összefüggés miatt a melyreállítását célozza az FMT. A randomizált vizsgálatok elemzése alapján az FMT szignifikánsan növeli a remisszió és a válaszkészség arányát. Azonban nincs még egyetértés a transzplantátum-elkészités módjában, a beadott szükséges mennyiségben és gyakoriságban, a donor és betegszelekciós kritériumaiban gyes vizsgálatok pl. a recipiens FMT előtti magasabb C. albicans jelenlétét az FMT-re adott válasz jó prediktorának tartják. A viromban a Caudovirales bakteriofágok gyakoriságának jelentős növekedését figyelték meg. A nem randomizált tanulmányokban a CU-s betegek $50 \%$-a mutatott javulást a beavatkozás hatására, 20\%-a pedig klinikai remisszióba került. A különböző metodigálatok CU-ban az indu klinikai és/vagy endoszkópos remissziós arányt mutatnak $(9,10)$.

Crohn-betegség

Sajnos a Crohn-betegségben az FMT hatásosságával kapcsolatos evidenciák hiányosak. Egy alkalommal alkalmazott transzplantáció hatékonysága csak mérsékeltnek mondható, kevésbé találták hatásosnak mint CU-ban. Egy metaanalízis 33,3\%-os remissziós rátát igazolt $(10,11)$. Ma még nem áll rendelkezésünkre olyan marker, amelynek segítségével az FMT-re adott választ elöre jelezhetnénk. A rendelkezésre álló tanulmányok a betegszelekció a homogenizátum elkészítési módja, az adagolás dózisa módja, az utánkövetési idő és a kimenetelek tekintetében heterogének. 


\section{Irritábilis bélszindróma (IBS)}

Az IBS-ben szenvedô betegek egy részében megváltozot a bélfóra összetétele az egészséges kontrollhoz képest. Összefüggést is találtak a panaszok súlyossága és mikrobomban bekövetkezett változások között. Az FMT IBS-ben betöltött szerepét vizsgáló placebokontrollált randomizált kontrollált tanulmány alapján gasztroszkópia során duodenumba juttatott 30, illetve $60 \mathrm{~g}$ székletpreparátum a betegek 77 és 89\%-ában eredményezett tüneti javulás szemben a placebocsoportban észlelt 24\%-kal (12). A tüneti javulás mellett szignifikáns volt a fáradékonyság és az életminőség javulása is a vizsgálatban.

\section{Metabolikus betegségek}

Nehảny kutatás az inzulinrezisztencia, obesitas, nemalkoholos zsirmaj es steatohepatitis, az ateroszkklerózis, a hipertónia és a dysbiosis kozottt talált asszociációt, azonban a rendelketudtak egyértelmú választ adni (13). Péterfi és munkatársai tudtak egyértelmú választ adni (13). Péterfi és munkatársa c. diffficie miatt végzett FMT során 2-es tipusú cukorbetegeknél inzulinrezisztencia csokkenést figyeltek meg. Hasonló

MDR-kórokozók által okozott visszatérô fertőzések, kolonizáció kezelése

Több vizsgálat foglalkozik annak lehetöségével, hogy a multidrug-rezisztens kórokozók által okozott colonkolonizációt, ilszáco" uroinfekcó́kat sikeresen megszïntesse FMT-VI(15).

\section{A donor szürésének kritériumai}

A donor megválasztása során arra kell törekedni, hogy az rövid- és hosszú távon se veszélyeztesse a recipienst, így a szưrés során az át whíctó fertón betegségek és az MDR-kohabitussal rendelkezzen és nos. Adenvedjen daganatos vagy krónikus anyagcsere-betegségben. A donor szürését állapotfelmérés (előző fél évben történő gyógyszerszedés, allapós életvitel krónikus betegség széklethabitus) utánél talános vérvétel és a széklettel is átvihető fertőző ágensek jenlétének kizárás követ Szürni kell HAV, HBV, HCV, HEV EBV, CMV, HIV, lues, toxoplasma, székletparazta bak, ́rium és C difficile toxin és antigén irányában. MDR-kolonizálo baktériumok kizárására anustörlést kell végezni $(1,8)$. A COVID-19-pandémia a SARS-CoV-2 potenciális vesze lyeire is felhívja a figyelmet. Tekintettel arra hogy a kereskedelmi forgalomban lévő tesztek rutinszerüen kealkalmasak a székletben lévő vírus kimutatására és az gyógyulást követően még sokáig ürülhet nagy elővigyá zatosságot és megfontolást követel. laniro és munkatársa zatossägot és megegfontolàst kóvetel. laniro és munkatärsai CoV-2 virus átvitele nagy biztonsággal megelőzhető (16)

\section{Az FMT kivitelezése}

Az elmúlt években számos módszert kipróbáltak a donorszéklet recipiensbe juttatására. Ennek megfelelően hasz nálhatunk friss székletet, valamint preparált székletet, am lehet fagyasztott (-80 ${ }^{\circ} \mathrm{C}$ fokon) vagy liofilizált széklet. A friss székletet 6 órán belül fel kell használni, a fagyasztott széklet kb. 6 hónapig tárolható, míg a liofilizált széklet megfelelô A filmenyek mellett akár korlátlan ideig is tárolható lehet. A fagyasztott széklethomogenizátum előnyben részesítendó a friss széklet homogenizátummal szemben $C$. difcile-infekcióban.

Az egyes preparátumok hatékonyságát több kutatás és metaanalízis is összehasonlította és nem talált szignifikâns eltérést a friss vagy fagyaszzott széklet hatékonysága kozott (17). Vigvári és munkatársai a liofilizált székletpreatékonynak találták, mint a fris letet $(18,19,20)$

Alsó tápcsatornai beadás

z alsó tápcsatornai bevitel történhet beöntés, enema formájában vagy pedig kolonoszkóp segítségével. A kolonöl történik aran, az endoszkóp munkacsatornająn kereszészítmény a szeklet-homogenizútum beadása. A székletérzető ến esetén is alkalmazható a beadási mód, mivel az egyéb

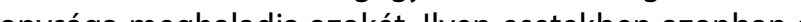
knysága meghaladja azoket. lyen esetekbe

cö̌kenáseadása háton fekve javasolt, a székelési inger csokszabb ide hörźno bent tartása szäksé 30 percig a belrendszerben ció eléréséhez.

位

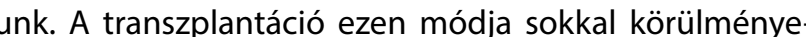
sebb és költségesebb (21).

Felső tápcsatornai beadás

A felső tápcsatornai beadás nasogastricus, nasoduodenalis, nasojejunalis szondán/tápszondán, gastrostomán keresztül vagy gasztroszkópia során, a munkacsatornán keresztül történhet, amennyiben klinikailag nincs nyelészavarra utaló tünet és nem áll fenn az aspiráció, regurgitáció veszélye és a beteg megfeleló bélmotilitással rendelkezik. Hányinger, hányás miatt aspirációs penumónia, láz, kontaminált vékonybél-szindróma alakulhat ki mellékhatásként. Vigváriés munkatársai igazolták, hogy a nasogastricus vagy nasojejunalis szondán át alkalmazott beviteli mód egyforma eredménnyel jár $(22,23)$.

A kapszulázott székletkészítmények alkalmazása egyszerúbbé, jobban tolerálhatóbbá teszi a transzplantátum beadását. Az eddigi tapasztalatok alapián mellékhatások előfordulási gyakorisága igen ritka. A betegek jobban toleálják kontaminált vékonybél-szindróma kialakuláśával aspiráció veszélyével nagyon ritka esetben lehet számoln aspiráció veszélyével nagyon ritka esetben lehet számolni, szabadulása már a terminális ileumban történik.

Péterfi és munkacsoportja az elmúlt időszakban végzett megfigyeléses vizsgálata alapján, 30 betegnél a baktériummentes székletpreparátum kapszulában történóa alkalmazása ugyanolyan hatékonynak bizonyult mint a teljes széklettel végzett transzplantáció (23).

\section{Az FMT hatására bekövetkező változások} (feltételezett hatásmechanizmus)

Az FMT kiváló hatásának mechanizmusa ma még tisztá zatlan. Sokáig abból indultunk ki, hogy a hatás az átvitt baktériumpopulációnak köszönhető. Ezzel szemben több vizsgálatban is azt mutatták ki, hogy CDI esetén a bakté riumok ebben legfeljebb csak alárendelt szerepet játszanak. Kiújuló C. difficile-fertőzésben szenvedó betegek kis csoportjába (5 beteg) Ott és munkacsoportja, illetve nagyobb betegcsoportban (30 beteg), Péterfi munkacsoportja, a széklet steril szürletét juttatták be. A szürletben csak a baktériumoknál kisebb részecskék lehettek jelen. Ezzel a módszerrel is meg lehetett gyógyítani a betegeket, és egyidejüleg a mikrobiom is normalizálódott. Elképzelhetö, hogy az átvitt bakteriofágokban különösen a Caudovirales taxon bakteriofágjaiban kereshetjük ennek a megdöbben-

Mikrobák változása

C. difficile-fertőzésben a megelöző antibiotikumkezelés hatására a spórák vegetatív formává alakulnak, ezt követően A- és B-toxint termelnek, aminek hatására hasmenés alakul ki. Mindezek mellett a normál bélflóra diverzitása és a baktériumszám csökkenése teret enged a $C$. difficile elszaporodásának. Az FMT célja az, hogy ezt a mikroflórát helyreallitsa. Gyulladásos belbetegségben a béfllór osszetételeben láthatúl éteréseket. Itt a nómállóra bélfóra meáltoztása ́́lő batériumokkat lohetséges. FMT ún a doñ jö mikrobiom figyelhető mes. CDI-ben a mikrobák változása másodion het miv la betegek zömoza transzplantáció után röviddel, 48 órán beül panaszainak nyhülését jelí Azidö rövidsége nem elég a donorfór kolonizációjáh ś́hoz téńt valmi más tényző miatt lesznok a betegjozi Azonban stabil állapot fentartásában az új rának valószinüleg jelentős szerepe lehet.

Bakteriofág-változások

A bakteriofágok olyan vírusok amelyek különböző baktériumokra specialiźltan élősködnek és pusztiják bakkülönböző vizsgálatok azt mutatják hogy a bakk erió gok (Caudovirales) mennisége jelentósen megváltozik $A$ gok (Caudovirales), mennyisége jelentósen megvaltozik. A dovirales mennyisége a donorszékletben. Egy követéses vizsgálatban a CD miatt végzett FMT-t követóen a donervirom legaláb

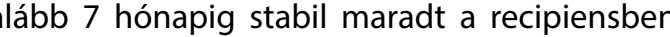
$(26,27)$

Mycobiota változások

A gombákat érintó változások azt mutatják hogy CD miatt végzett FMT sikeres transzplantáció esetén különböző donorgombákkal megtörténik a kolonizáció. Ezek saccharomyces és Aspergillus genusba tartoznak míg a sikertelen transzplantáció esetén a Candida faj a domináns. BD esetében Basidiomycota/Ascomycota arány magas, S. cerevisiae alacsony míg a Candida albicans magasabb arányban fordul elő, mint az egészséges populációban.
Az FMT elötti magas Candidasưrúség szoros összefüggést mutatott a klinikai javulással. Éppen ezért azt gondolják hogy a magas Candida mennyiség a transzplantáció elöt egtheti a beültetett baktériumok megtapadását, ökoló giai rések biztositásával $(28,29)$

\section{Metabonomika}

A metabonomika a különböző gyógyszeres vagy egyéb intervenciók hatására bekövetkező metabolikus válaszokat vizsgálja. Az FMT esetében kitüntetett szereplők a rovid szénlancú zsirsavak (SCFA). Egerekben azt találták, hogy a magas SCFA jelenléte protektív tényezökén hatort a C. dif ílle novekedés gátlásában. A valerát butirát, acetát és propionát ilyen szempontból szintén fontos védőhatással rendelkezhetnek (30).

Egyes vizsgálatok eredményei arra utalnak, hogy a bélmik rólális SCFA-termelók FMT-n kereszzül történő helyreállitása az immunológiai reakciók szabályozását és homeoszA másik fon tos metabolit az epesav. Az elsődlet IBD-ben. A másik fontos metabolit, az epesav. Az elsodleges epesavak, pla a konjugát taurochósav glicin jelentéében segiti cát. Ezzel szeranen a másodlagos epesavak mint a deo-

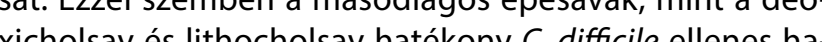
tással rendelkeznek a vegetatív formák szaporáśna és toxinterméśn, a vétláśt

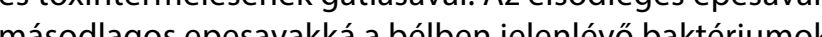

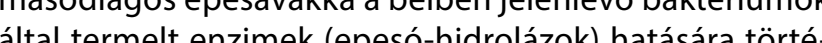
nik. Az FMT-vel visszaállitott epemetabolizáló képessé

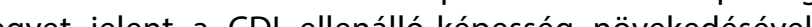
visszaállításával.

A rövid szénláncú zsírsavak ugyanakkor a regulátor T-sejek mennyiségét és funkcióját is jótékonyan képesek be-

Colitis ulcerosában egy kisérletes modellben a hippuronsav játszhat szerepet a tünetek csökkentésében, illetve annak hiányában a tünetek erősödésében. A hippuronsav-változást az Oscilospira, Dahalobacterium, Exiguobac teriaceae és a Bacillaceae családhoz köthetjük $(31,32)$.

mmunológiai mechanizmusok

A bélmikrobiom fontos szerepet játszik a mucosalis immunitás megfelelő múködésében, az immunmoduláció révén az egész szervezet immunrendszerét is szabályozhatja. FMT mellett megfigyelték, hogy a transzplantáció után a dendritikus sejtek, monocyták, makrofágok MHC II dependens bakteriális antigénprezentáló képessége csökken. A veleszületett és adaptív immunmechanizmusok megzavarása alapvető fontosságúnak tủnik a krónikus immunmediált betegségek, például az IBD kialakulásában. Ma már egyre több bizonyíték utal arra, hogy az ezekben a betegségekben megfigyelt bélmikrobiális perturbáciok hozzáajrulnak ennek a homeosztatikus immunológia egyensúlyhiánynak a kialakulásához. IBD-s beteg egérmatorikus Th17-sejtek számát és csökkentette a RORyt+ matorikus Th17-sejtek számát és csökkentette a RORүt+ képest. IBD-exacerbáció esetén szoros összefüggést lehetett megfigyelni ezen proinflammatorikus változások és 
az aktivitás mértéke között. FMT után Quirashi és munkatársai szignifikáns növekedést észleltek az IL-10-termelő CD4-sejtekben és szignifikáns csökkenést az IL-17-termelö CD4- és CD8-sejtpopulációban. Összességében elmondható, hogy az FMT és a bélmikrobiota posztbiotikus termékei csökkenthetik a gyulladást a regulátor T-sejtek modulálása révén $(33,34)$.

\section{Következtetések}

Az FMT bizonyította helyét a rekurráló $C$. difficile colitis kezelésében, azonban még további vizsgálatok szükségesek annak eldöntésére, hogy milyen egyéb megbetegedéseket és hogyan kezeljünk ezzel az ígéretesnek tűnő módszerrel. A pontos hatásmechanizmus felderítése hosszabb idejü, intenzív kutatómunkát igényel. A donorok szűrésének kritériumai és az egyénre szabott terápia meghatározása terén az ismeretek bővülése folyamatos változtatásokat tesz szükségessé. A metagenomika ezen kérdések megválaszolásában sokat segíthet, amíg azonban elérhetővé nem válik, a megfontolt indikációjú alkalmazását javasoljuk.

Az FMT általánosságban véve biztonságos módszer, amennyiben a donorszűrések megfelelő szigorúsággal történnek. A rövidtávú jelentős kockázatok elsősorban a

\section{Irodalom}

1. Bálint Anita, Born Alexandra, Fried Katalin, Lovász Barbara Dorottya, Palatka Károly, Péterfi Zoltán, Prinz Gyula, Szamosi Tamás, Varga Márta, Farkas Klaudia, Wittmann Tibor, Visontai Ildikó: Az Emberi Erőforrások Minisztériuma egészségügyi szakmai irányelve a hagyományos széklettranszplantációs eljárás kivitelezéséről. Egészségügyi Közlöny 2020; 70(12): 1658-1681.

2. FDA report. Fecal Microbiota for Transplantation: Safety Alert - Risk of Serious Adverse Events Likely Due to Transmission of Pathogenic Organisms https: //www.fda.gov/safety/medical-product-safety-information/ fecal-microbiota-transplantation-safety-alert-risk-serious-adverse-eventslikely-due-transmission

3. Gupta S, Parker J, Smits S, Underwood J, Dolwani S. Persistent vira shedding of SARS-CoV-2 in faeces - a rapid review. Colorectal Dis 2020 22(6): 611-620.

doi: $10.1111 /$ codi.15138

4. Debast SB, Bauer MP, Kuijper EJ; European Society of Clinical Microbiology and Infectious Diseases. European Society of Clinical Microbiology and Infectious Diseases: update of the treatment guidance document for Clostridium difficile infection. Clin Microbiol Infect 2014; 20(Suppl 2): 1-26. doi: 10.1111/1469-0691.12418

5. McDonald LC, Gerding DN, Johnson S, Bakken JS, Carroll KC, Coffin SE, Dubberke ER, Garey KW, Gould CV, Kelly C, Loo V, Shaklee Sammons J, Sandora TJ, Wilcox MH. Clinical Practice Guidelines for Clostridium difficile Infection in Adults and Children: 2017 Update by the Infectious Diseases Society of America (IDSA) and Society for Healthcare Epidemiology of America (SHEA), Clinical Practice Guidelines for Clostridioides difficile Infection. Clin Infect Dis 2018; 66(7): e1-e48.

doi: $10.1093 / \mathrm{cid} / \mathrm{cix} 1085$

6. OEK Módszertani Levele. A Clostridium difficile fertőzések diagnosztikájáról, terápiájáról, 2. átdolgozott kiadás.

7. Tschudin-Sutter S, Kuijper EJ, Durovic A, Vehreschild MJGT, Barbut F, Eckert C, Fitzpatrick F, Hell M, Norèn T, O'Driscoll J, Coia J, Gastmeie $\mathrm{P}$, von Müller L, Wilcox MH, Widmer AF; Committee. Guidance document for prevention of Clostridium difficile infection in acute healthcare settings. Clin Microbiol Infect 2018; 24(10): 1051-1054.

doi: 10.1016/j.cmi.2018.02.020

8. Cammarota $\mathrm{G}$, laniro $\mathrm{G}$, Tilg $\mathrm{H}$, et al. European consensus conference on faecal microbiota transplantation in clinical practice. Gut 2017; 66(4): 569-580. doi: 10.1136/gutjnl-2016-313017

9. Costello SP, Hughes PA, Waters O, Bryant RV, Vincent AD, Blatchford P, Katsikeros R, Makanyanga J, Campaniello MA, Mavrangelos C, Rosewarne CP, Bickley C, Peters C, Schoeman MN, Conlon MA, Roberts-Thomson IC, Andrews JM. Effect of fecal microbiota transplantation on 8-week remission in patients with ulcerative colitis: A randomized clinical trial. JAMA 2019; 321(2): 156-164.

doi: $10.1001 / j a m a .2018 .20046$ beviteli módszerrel kapcsolatos szövődményekkel függenek össze (pl. kolonoszkópos bevitel okozta szövődmények), míg a gyakrabban előforduló mellékhatások, mint például hasmenés, hasi fájdalom, puffadás enyhék, átmenetiek, és sokszor spontán rendeződnek. Ritkán előforduló szövődmény lehet antibiotikumrezisztens baktériumok átvitele, ami jól szabályozott donorszűréssel vagy baktériummentes preparátum használatával kiküszöbölhető. Fatális kimenetelt is leírtak FMT kapcsán, de sok esetben nem dönthető el, hogy az a beavatkozás következménye vagy a súlyos állapotú betegnél a módszer alkalmazása nélkül is bekövetkezett volna. A hosszú távú kockázatok kevésbé ismertek. A potenciális patogének átvitelén túl metabolikus változások (elhízás, inzulinrezisztencia), daganatos betegségek, neuropszichiátriai eltérések kialakulásának kockázata is felmerül FMT kapcsán, de ezek a lehetséges asszociációk egyelőre nem bizonyítottak. A kezelésben részesültek hosszú távú utánkövetése a fentiek miatt kiemelt fontosságú, a módszert rutinszerűen alkalmazó ellátóhelyeken ez általában meg is történik, és többéves utánkövetés kapcsán sem merült fel eddig jelentős szövődmény.

A többszörösen rekurráló vagy refrakter $C$. difficile colitis indikációján túl egyelőre csak klinikai vizsgálatok keretében jön szóba az FMT alkalmazása.

10. Paramsothy S, Paramsothy R, Rubin DT, Michael A. Kamm, Nadeem O. Kaakoush, Hazel M Mitchell, Natalia Castaño-Rodríguez. Faecal Microbiota Transplantation for Inflammatory Bowel Disease: A Systematic Review and Meta-analysis. J Crohns Colitis 2017; 11(10): 1180-1199.

doi: 10.1093/ecco-jcc/jjx063

11. Gutin L, Piceno Y, Fadrosh D, Lynch K, Zydek M, Kassam Z, LaMere B, Terdiman J, Ma A, Somsouk M, Lynch S, El-Nachef N. Fecal microbiota transplant for Crohn disease: A study evaluating safety, efficacy, and microbiome profile. United European Gastroenterol J 2019; 7(6): 807-814. doi: $10.1177 / 2050640619845986$

12. El-Salhy M, Hatlebakk JG, Gilja OH, Krostoffersen AB, Hausken T: Efficacy of faecal microbiota transplantation for patients with irritable bowel syndrome in a randomised, double-blind, placebo-controlled study. Gut 2020; 69: 859-867.

doi: $10.1136 /$ gutjnl-2019-319630

13. Vrieze A, Van Nood E, Holleman F, Salojärvi J, Kootte RS, Bartelsman JF, Dallinga-Thie GM, Ackermans MT, Serlie MJ, Oozeer R, Derrien M, Druesne A, Van Hylckama Vlieg JE, Bloks VW, Groen AK, Heilig HG, Zoetendal EG, Stroes ES, de Vos WM, Hoekstra JB, Nieuwdorp M.. Transfer of intestinal microbiota from lean donors increases insulin sensitivity in individuals with metabolic syndrome. Gastroenterology 2012; 143(4): 913-6.e7.

doi: 10.1053/j.gastro.2012.06.031

14. Kootte RS, Levin E, Salojärvi J, et al. Improvement of Insulin Sensitivity after Lean Donor Feces in Metabolic Syndrome Is Driven by Baseline Intestinal Microbiota Composition. Cell Metab 2017; 26(4): 611-619.e6.

doi: 10.1016/j.cmet.2017.09.008

15. Grosen AK, Povlsen JV, Lemming LE, Jørgensen SMD, Dahlerup JF, Hvas CL. Faecal Microbiota Transplantation Eradicated Extended-Spectrum Beta-Lactamase-Producing Klebsiella pneumoniae from a Renal Transplant Recipient with Recurrent Urinary Tract Infections. Case Rep Nephrol Dial 2019; 9(2): 102-107. Published 2019 Aug 20.

doi: $10.1159 / 000502336$

16. laniro G, et al. Reorganisation of faecal microbiota transplant services during the COVID-19 pandemic. Gut 2020; 0: 1-9.

doi: 10.1136/gutjnl-2020-321829

17. Fang H, Fu L, Wang J. Protocol for Fecal Microbiota Transplantation in Inflammatory Bowel Disease: A Systematic Review and Meta-Analysis. Biomed Res Int. 2018; 2018: 8941340. Published 2018 Sep 13.

doi: $10.1155 / 2018 / 8941340$

18. Vigvari Szabolcs, Sipos Dávid, Solt Jenő, Vincze Áron, Kocsis Béla Nemes Zsuzsanna, Kappéter Á, Feiszt Zs, Kovács B, Péterfi Z. Faecal microbiota transplantation for Clostridium difficile infection using a lyophilized inoculum from non-related donors: A case series involving 19 patients. Acta Microbiol Immunol Hung 2019; 66(1): 69-78.

doi: 10.1556/030.64.2017.042

További irodalom megtalálható a szerkesztőségben, valamint a www.gastronews.olo.hu weboldalon. 